\title{
Influence of ZnO nanocrystals surface modification on structure and photovoltaic properties of $\mathrm{MEH}-\mathrm{PPV} / n c-\mathrm{ZnO}$ nanocomposite films
}

\author{
N.V.Babayevskaya, Yu.N.Savin, O.O.Matvienko, V.V.Varchenko", \\ A.P.Kryshtal*, M.F.Prodanov*, Yu.A.Gurkalenko**, \\ V.V.Vaschenko", V.P.Seminozhenko
}

Institute for Single Crystals, SSI "Institute for Single Crystals", National Academy of Sciences of Ukraine, 60 Lenin Ave., 61001 Kharkiv, Ukraine "Division of Chemistry of Functional Materials, SSI "Institute for Single Crystals", National Academy of Sciences of Ukraine, 60 Lenin Ave., 61001 Kharkiv, Ukraine

*Institute for Scintillation Materials, SSI "Institute for Single Crystals", National Academy of Sciences of Ukraine, 60 Lenin Ave., 61001 Kharkiv, Ukraine

Received October 10, 2013

The influence of interface modifires based on perylen imide dyes and naphthyl phosphonic acid on MEH-PPV/nc-ZnO nanocomposite films morphology was stydied. The better phase compatibility between MEH-PPV and $n c-\mathrm{ZnO}$ was obtained if (PI1) and (PI2) were used as the IMs. Use of the IMs led to decrease the fluorescence lifetime quenching $\left(\tau_{1}\right)$ and to increase the quenching efficiencies $\left(\eta_{q}\right)$. It was demonstrated that all IMs increase $J_{S C}$ and $V_{O C}$.

Исследовано влияние интерфейсных модификаторов на основе перилена и нафтил фосфоновой кислоты на морфологию пленок $\mathrm{MEH}-\mathrm{PPV} / n c-\mathrm{ZnO}$. Наилучшая фазовая совместимость наблюдалась для MEH-PPV и $n c-\mathrm{ZnO}$ при использовании модификаторов (PI1) и (PI2). Использование модификаторов приводит к снижению тушения времени жизни флуоресценции $\left(\tau_{1}\right)$ и увеличению әффективности переноса заряда $\left(\eta_{q}\right)$. Показано, что использование всех модификаторов привело к увеличению $J_{S C}$ и $V_{O C}$.

Вплив модифікацї̈ поверхні нанокристалів ZnO на структуру та фотовольтайчні властивості нанокомпозитних плівок МЕН-PPV/nc-ZnO. Н.В.Бабаєвська, Ю.М.Саввін, О.О.Матвієнко, В.В.Варченко, О.П.Кришталь, М.Ф.Проданов, Ю.О.Гурка ленко, В.В.Ващенко, В.П.Семіноженко.

Досліджено вплив інтерфейсних модифікаторів на основі перилену та нафтилфосфонової кислоти на морфологію плівок MEH-PPV/nc-ZnO. Найкраща фазова сумісність спостерігається для MEH-PPV i $n c-Z n O$ при використанні модифікаторів (PI1) i (PI2). Використання модифікаторів призводить до зниження гасіння часу життя флуоресценції $\left(\tau_{1}\right)$ та збільшенню ефективності переносу заряду $\left(\eta_{q}\right)$. Показано, що використання усіх модифікаторів призвело до збільшення $J_{S C}$ та $V_{O C}$. 


\section{Introduction}

A bulk heterojunction (BHJ) photovoltaic (PV) device on the base of hybrid photoactive films comprising the photosensitivity polymer (donor) and semiconductor nanocrystals (acceptor) are of great interest as an alternative for $\mathrm{Si}$ based energy sources [1]. BHJ photovoltaic cells usually include a large number of donor/acceptor interfaces for charge separation at the expense of discontinuous transport pathways by hopping. In these hybrid photovoltaic cells the recombination occurs almost exclusively at the heterojunction and the exciton dissociation efficiency is strongly dependent on the type of nanocrystals dispersion or phase segregation in polymer matrix, which are thereby crucial for the PV device performance. Thus, one of the key issues for fabrication of the efficient photovoltaic devices is morphology control of the BHJ active layer [2-5].

Usually these processes can be controlled by nanoparticles surface modification with suitable surfactants (interface modifiers, IMs) [6, 7]. Structure of the typical IMs consists of polar thiol-, amino-, mercaptoor phosphonic heads as anchoring groups, and conjugated molecular backbone [8]. Role of the IMs reveals in enhancement of the chemical compatibility between polymer and semiconductor nanoparticles, increasing the excitons separation efficiency at the polymer/nanoparticle interface and subsequent charge transfer rate into the nanoparticle bulk, reduction of interfacial recombination and improvement of a charge transport in polymer matrix as a result of the macromolecules ordering in the polymers [9].

As promising candidates for conjugated backbone groups, oligoarenes and organic dyes can be considered. However, only several research groups modified the surface of metal-oxide nanoparticles with different dyes: mercurochrome [10], N719 dye [11], as well as 2-amino-1-methylbenzimidazole [8], 2-naphthalenethiol (2-NT) [9], anthracene-9carboxylic acid (ACA), tetracarboxy phthalocyanine copper (II) (CuPc-dye) and N3-dye [12], oligothiophenic phosphonic acids [13] and peryleneimide dyes (PIs) [14-17]. As a result, substantial improvement in short-circuit current density $\left(J_{S C}\right)$, open-circuit voltage $\left(V_{O C}\right)$ and fill factor $(F F)$ of the modified device were obtained. Influence of the chemical structure of phosphonic acid containing interface modifiers of $\mathrm{TiO}_{2}$ on photoinduced properties of the layered-junction
$\mathrm{TiO}_{2} / \mathrm{IMs} / \mathrm{P} 3 \mathrm{HT}$ was investigated in [13]. Both photoluminescence (PL) and PL lifetime measurements suggested that the photoinduced transfer of electrons from P3HT to $\mathrm{TiO}_{2}$ increased as the conjugation length of molecular backbone increased or as the nonconjugated chain-length in IMs decreased. Moreover, molecular structure of the IMs strongly affected the photovoltaic cell performance of the layered device $\mathrm{ITO} / \mathrm{TiO}_{2} / \mathrm{IM} / \mathrm{P} 3 \mathrm{HT} / \mathrm{Au}$ through their energy levels and charge transfer ability. The $J_{S C}$ increased and $V_{O C}$ reduced as number of thiophene rings increased and length of the insulating chain in the IMs decreased.

Peryleneimide dyes represent one of the most widely studied classes of organic semiconductors for applications in solid-state dye-sensitized solar cells (DSSCs) [14, 17]. It is known that the majority of organic conducting materials are $p$-type semiconductors whereas PIs are $n$-type semiconductors [18]. Such materials possess high electron mobility [19], specific carrier injection-tuning properties [20], large molar absorption coefficients [21] in combining with excellent photo [22] and thermal stabilities [23]. Physical properties of PI dyes can be tuned by introduction of appropriate substituents in imide or bay positions, which is important in design of the new materials for PV applications [15, 16]. A perylene derivative was used to enhance the photoelectric efficiency of the hybrid poly(3-hexylthiophene)/ZnO bulk-heterojunction solar cells [17].

Although most of the cited above works are devoted to application of the PI dyes as sensitizers in DSSCs, effect of the PI dyes as the IMs on the active layer morphology and photovoltaic properties of solar cells was not studied practically. We know one work only devoted to the effect of perylen dye (perylenetetracarboxylic acid diimide) ligand shell formed on Au nanoparticles on morphology of the active layer and photovoltaic properties of solar cells [24].

In this work, we study the effects of the interface modifiers formed at $\mathrm{ZnO}$ nanocrystals surface on the MEH-PPV/ZnOnanocrystals morphology, luminescence and photovoltaic properties of the photoactive layers in polymer-inorganic BHJ photovoltaic cells.

\section{Experimental}

Colloid solution of $\mathrm{ZnO}$ nanocrystals stabilized with methanol (native ligand shell) $(n c-\mathrm{ZnO}(\mathrm{Nat}))$ in cholorobenzene was ob- 

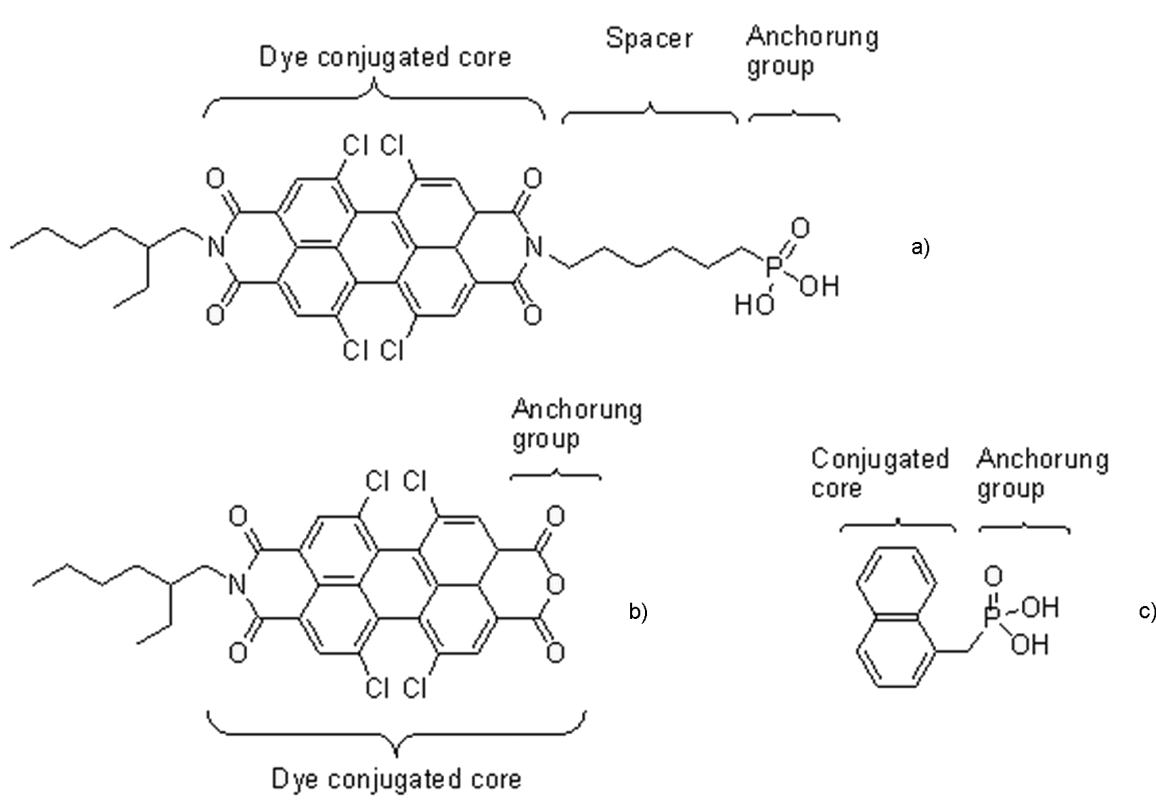

Fig. 1. Structures of IM: a - PI1, b - PI2 and c - NPA.

tained using method described previously in [25], the nanocrystal average size was $~ 3.5 \mathrm{~nm}$, as was determined by TEM. Concentration of $n c-\mathrm{ZnO}$ (Nat) in the colloids was $60 \mathrm{mg} \cdot \mathrm{ml}^{-1}$. Photosensible conjugated polymer MEH-PPV, chlorobenzene and ITO glass substrates were purchased from Sigma-Aldrich, Inc. The polymer had the number average molecular weight, $M_{n}=$ 40,000-70,000 and polydispersity $\left(M_{w} / M_{n}\right)$ of about 5 .

Unsymmetrical substituted perylene imide dyes N-(2-ethylhexyl)-N'-(6-phosphono-hexyl)-1,6,7,12-tetrachloro-perylene $-3,4,9,10$-tetracarboxylic acid bisimide (PI1) and N-(2-ethylhexyl)-1,6,7,12tetrachloroperylene-3,4,9,10-tetracarboxylic acid-3,4-anhydride-9,10-imide (PI2) were synthesized starting from 3,4,9,10-tetracarboxylic acid-3,4,9,10-dianhydride similarly to described in [26]; details of the synthesis and isolation of target compounds will be published elsewhere. We used 1-naphthyl phosphonic acid (NPA) (Sigma-Aldrich) also to compare effect of small conjugative molecules without a long alkyl chains. $\mathrm{ZnO}$ nanocrystals with modified surface ( $n c$ $\mathrm{ZnO}(\mathrm{IM})$ ) were obtained via heating of $n c$ $\mathrm{ZnO}$ colloids with an excess of appropriate surfactants (IM) at $50^{\circ} \mathrm{C}$ for $20 \mathrm{~h}$ similarly as it was described in [27].

Blend films were prepared by adding colloid solution of modified $n c-\mathrm{ZnO}(\mathrm{IM})$, to MEH-PPV solutions in chlorobenzene at concentration of $6 \mathrm{mg} / \mathrm{ml}$. The mass ratio of $\mathrm{MEH}-\mathrm{PPV} / n c-\mathrm{ZnO}$ was of $1: 2$. A typical
$\mathrm{MEH}-\mathrm{PPV} / n c-\mathrm{ZnO}(\mathrm{IM})$ film thickness was 70-80 nm.

Reduction $E_{r e d}$ and oxidation $E_{o x}$ potentials of the IMs were determined by cyclic voltammetry (CV) measurements (CH instruments (797 VA Computrace)) at a scan rate of $0.1 \mathrm{~V} / \mathrm{s}$ at the room temperature. Morphology of the MEH-PPV/NC(IM) blend films with ZnO-IM nanocrystal was studied by transmission electron microscopy (TEM), using Selmi TEM-125 microscope. Photoluminescence spectra were recorded using SDL-2 (LOMO, Russia) double-monochromator spectrometer. Fluorescence lifetimes were detected by a sub-nanosecond kinetic spectrometer, consisting of MDR-12 monochromator (LOMO, Russia), TimeHarp 200 TCSPC device, PLS 340-10 picosecond LED driven by PDL 800-B device (PicoQuant GmbH, Germany) and Hamamatsu H5783P PMT (Hamamatsu, Japan). $J-V$ characteristics were measured on the photovoltaic cells with the architecture ITO/PEDOTPSS/photoactive layer/Al with Amper-voltmeter W7-35 under $100 \mathrm{~mW} \cdot \mathrm{cm}^{-2}$ illuminations from a $100 \mathrm{~W}$ tungsten-halogen lamp. All measurements were performed at the ambient conditions.

\section{Results and discussion}

Structures of the studied interface modifier molecules (PI1, PI2 and NPA) are distinguished in the length of spacer, nature of anchoring group and expansion of conjugated $\pi$-electronic system (see Fig. 1). In order to reduce the tendency of perylenic 
Table 1. Results of cyclic voltammetry

\begin{tabular}{|c|c|c|c|c||}
\hline \hline $\mathrm{IM}$ & $E_{\text {red }}, \mathrm{eV}$ & $E_{g}, \mathrm{eV}$ & $\begin{array}{c}E_{L U M O}, \\
\mathrm{eV}\end{array}$ & $\begin{array}{c}E_{\mathrm{HOMO}}, \\
\mathrm{eV}\end{array}$ \\
\hline $\mathrm{PI} 1$ & -0.72 & 2.14 & -3.67 & -6.10 \\
$\mathrm{PI} 2$ & -0.51 & 2.23 & -3.89 & -6.23 \\
$\mathrm{NPA}$ & -1.01 & 3.73 & -3.38 & -7.3 \\
\hline
\end{tabular}

IMs to aggregates formation [28], and thereby to enhance the photoelectron transfer injection from the IMs to $n c-\mathrm{ZnO}$ and consequently to increase the $J_{S C}$ values [ 29 , $30]$, the structures of the chosen dyes contain four chlorine atoms in the bay position and branched terminal alkyl chain.

In order to determine the IMs reduction potential $\left(E_{\text {red }}\right)$ the cyclic voltammetry measurements were performed. HOMO and LUMO values of the IMs were estimated using equations [31]: $E_{L U M O}=\left[\left(E_{\text {red }}-\right.\right.$ $\left.E_{1 / 2(\text { ferrocene) }}+4.8\right]$ and $E_{H O M O}=E_{L U M O}-$ $E_{g}$, where $E_{1 / 2 \text { (ferrocene) is the average of }}$ the oxidation potential of ferrocene as an external standard. Results of the cyclic voltammetry are presented in Table 1 .

In BHJ devices the hybrid films morphology is one of the key parameters in achieving the device optimal performance. The TEM pattern for the blend films is different essentially for various IMs (see Fig. $2 a-2 d$ ). When $n c-\mathrm{ZnO}$ coated with the native ligand shell (i.e. as synthesized) are used (nc$\mathrm{ZnO}(\mathrm{Nat})$ ), the phase segregation in $\mathrm{MEH}$ $\mathrm{PPV} / n c-\mathrm{ZnO}$ (Nat) films is observed, i.e. $n c$ $\mathrm{ZnO}$ form the aggregates comprising closepacked nanoparticles (Fig. 2a). The distance between these aggregates exceeds considerably the exciton diffusion length $L_{d} \sim$ $10 \mathrm{~nm}$ in MEH-PPV polymer [32]. In the $\mathrm{MEH}-\mathrm{PPV} / n c-\mathrm{ZnO}(\mathrm{NPA})$ blend film the phase segregation also takes place (Fig. 2b). However, the adjacent $\mathrm{ZnO}$ nanocrystals in the aggregates are separated by thin polymer layer of $\sim 6 \mathrm{~nm}$ thickness which is less than $L_{d}$. In contrast to the both above-mentioned blend films, in the case of MEH$\mathrm{PPV} / n c-\mathrm{ZnO}(\mathrm{PI} 2)$ blend films the phase segregation occurs on a nanometer scale (Fig. 2d), i.e. the small sized rod-like aggregates of $n c-\mathrm{ZnO}$ are formed which are distributed homogeneously in the polymer matrix. Finely, the random distribution of $n c$ $\mathrm{ZnO}(\mathrm{PI1})$ is observed for the $\mathrm{MEH}-\mathrm{PPV} / n c-\mathrm{ZnO}(\mathrm{PI} 1)$ blend films. It can be assumed that the bulkier molecules of PI1 and PI2, in comparison with NPA, provide an effective interaction with polymer host and thus prevent the nanocrystals ag-
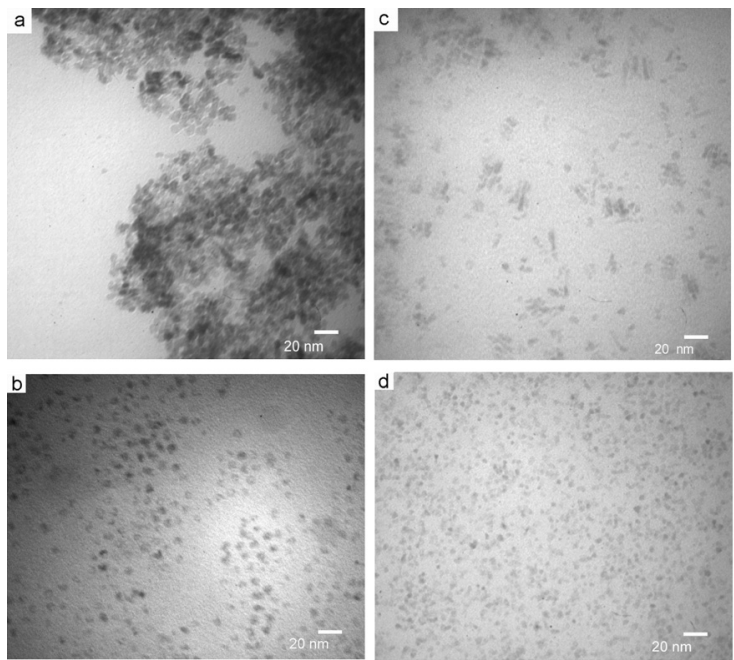

Fig. 2. TEM image of MEH-PPV/nc-ZnO(IM) blend films, containing $\mathrm{ZnO}$ nanocrystals with different interface modifiers: a IM(Nat); b - IM(NPA); c - IM(PI2); d IM(PI1).

gregation and macroscopic phase separation in course of the film preparation. Thus, the phase states of polymer/nc-ZnO(IM) blend films can be controlled with the balance between number and size of aliphatic and aromatic fragments in the IMs molecules.

To examine the effect of interface modification on charge carrier transfer, the time-resolved photoluminescence (TRPL) and photoluminescence quenching measurements in the bulk (BHJ) and bilayer (BLHJ) heterojunction device configurations were performed. Using the BLHJ configuration allowed to eliminate influence of the phase segregation and charge collection effects [33] and to study the effect of the IM chemical structure on exciton decay in $\mathrm{MEH}-\mathrm{PPV} / n c-\mathrm{ZnO}(\mathrm{IM})$ heterostructures only.

In order to elucidate the relaxation dynamics in our blend films the TRPL measurements were performed. The data obtained by the least-squares fit revealed that all PL transient traces for $\mathrm{MEH}-\mathrm{PPV} / n c$ $\mathrm{ZnO}(\mathrm{IM})$ films with different IMs decay as bi-exponential function $I(t)=I_{10} \cdot \exp \left(-t / \tau_{1}\right)$ $+I_{20} \cdot \exp \left(-t / \tau_{2}\right)$, where $\tau_{1}$ and $\tau_{2}$ are fluorescence quenching lifetimes corresponding to two relaxation processes: a fast decay $\left(\tau_{1}\right)$ due to exciton dissociation at the MEH$\mathrm{PPV} / n c-\mathrm{ZnO}(\mathrm{IM})$ interfaces and a slow decay $\left(\tau_{2}\right)$ due to their direct recombination in the polymer bulk [34]. Presumably, the presence of pure MEH-PPV regions (free of $n c-\mathrm{ZnO}$ ) with sizes bigger than $L_{d}$, is the origin of $I_{02}$ quenching component in $I(t)$ and 
Table 2. Time-resolved photoluminescence and photoluminescence quenching characterictics of bilayer (BLHJ) and bulk (BHJ) heterojunction MEH-PPV/ZnO-NC containing ZnO nanocrystals with different IMs

\begin{tabular}{|c|c|c|c|c|c|}
\hline Active layer & $\begin{array}{c}\text { Type of hetero } \\
\text { junction }\end{array}$ & $\begin{array}{c}\text { etabZ ZA } \\
\text { a.u. }\end{array}$ & $\begin{array}{c}\eta_{B H J} / \eta_{B L H J}, \\
\text { a.u. }\end{array}$ & $\tau_{1}$, ps & $I_{10} / I_{20}$, a.u. \\
\hline MEH-PPV/NC(Nat) & BLHJ & 0.17 & - & 348 & - \\
\hline MEH-PPV/NC(Nat) & BHJ & 0.21 & 1.23 & 350 & 2.21 \\
\hline MEH-PPV/NC(NPA) & BLHJ & 0.45 & - & 334 & - \\
\hline MEH-PPV/NC(NPA) & ВНJ & 0.59 & 1.31 & 319 & 3.02 \\
\hline MEH-PPV/NC(PI1) & BLHJ & 0.38 & - & 312 & - \\
\hline MEH-PPV/NC(PI1) & BHJ & 0.94 & 2.57 & 301 & 10.64 \\
\hline MEH-PPV/NC(PI2) & BLHJ & 0.47 & - & 218 & - \\
\hline MEH-PPV/NC(PI2) & BHJ & 0.87 & 1.82 & 207 & 27.4 \\
\hline
\end{tabular}

nonzero $\tau_{2}$ at the TRPL measurements as well residual $\mathrm{PL}$ intensity at the $\mathrm{PL}$ quenching measurements. As it was found for the blend films containing surface-modified $n c$ $\mathrm{ZnO}$, the parameter $\tau_{1}$ depends from the type of IM molecules. Variation of $\tau_{2}$ is apparently attributed to the changing of the molecular structure of a polymer matrix at the intercalation of the nanoparticles owing to polymer $/ n c-\mathrm{ZnO}(\mathrm{IM})$ interaction [34]. In addition, the value of $I_{10} / I_{20}$, determining the relative contribution of fast and slow decay relaxation processes in the TRPL, depends on the IM type essentially. The reduced PL-decay lifetime for $n c-\mathrm{ZnO}(\mathrm{PI} 2)$ relatively $n c-\mathrm{ZnO}(\mathrm{Nat}), n c-\mathrm{ZnO}(\mathrm{PI} 1)$ and $n c$ $\mathrm{ZnO}(\mathrm{NPA})$ indicated the more rapid charge transfer from the polymer to $n c-\mathrm{ZnO}$ with IM(PI2) than with other modifiers.

The PL quenching efficiencies $\left(\eta_{q}\right)$ are defined as $\eta_{q}=1-\left(A_{I M} / A_{0}\right)$, where $A_{I M}$ and $A_{0}$ denote the area under the PL curves of $\mathrm{MEH}-\mathrm{PPV} / n c-\mathrm{ZnO}\left(\mathrm{IM}_{\mathrm{i}}\right) /$ substrate and pristine MEH-PPV/substrate, respectively [13]. The obtained PL quenching efficiency for BLHJ and BHJ as well lifetimes and ratio $I_{10} / I_{20}$ for the studied samples are presented in Table 2. The greatest $\eta_{B L H J}(\mathrm{PI} 2)=0.47$ and $\eta_{B L H J}(\mathrm{NPA})=0.45$ are for PI2 and NPA molecules, while for Nat and PI1 modifiers $\eta_{B L H J}$ are less, 0.17 and 0.38 , correspondingly. Therefore, we have concluded that the transfer carriers efficiency is higher for the IM(PI2) than for IM(Nat) and IM(PI1), if not to take into account the effect of NC distribution in MEH-PPV matrix.

As it follows from Table 2, the highest and almost equal values of quenching luminescence efficiency $\eta_{q}$ for BHJ cells are observed for IM(PI1) 0.94, and IM(PI2) 0.87, while PL-decay lifetime $\tau_{1}=207 \mathrm{~ns}$ is essentially smaller for IM(PI2) than for IM(PI1). This reveals that despite of the highest velocity of the charge transfer process from MEH-PPV macromolecules to $\mathrm{ZnO}$ nanocrystals with IM(PI2) in comparison with IM(PI1), the efficiency of an electron transfer in $\mathrm{MEH}-\mathrm{PPV} / n c-\mathrm{ZnO}(\mathrm{PI} 2)$ blend film, comprising the small size rod-like $\mathrm{ZnO}$ aggregates, is smaller than for $\mathrm{MEH}$ $\mathrm{PPV} / \mathrm{NC}(\mathrm{PI} 1)$ blend film, where $n c-\mathrm{ZnO}$ are distributed randomly.

It is worth to note that the decay lifetime $\tau_{1}$ values for BHJ and BLHJ cells with the same IMs are similar in contrast to the PL quenching efficiencies $\left(\eta_{q}\right)$ which depend on cell configurations. In the BLHJ cell configuration the quenching efficiency $\eta_{q}$ is determined by the IM molecular structure only. On the contrary, in the BHJ cell configuration $\eta_{q}$ values depend on the blend film morphology. The $\eta_{B H J} / \eta_{B L H J}$ ratio allows to eliminate the contribution in $\eta_{B H J}$ of molecular and energy structure of the IM and evaluate contribution of the film morphology only. From Table 2 is seen that $\eta_{B H J} / \eta_{B L H J}$ value (2.57) is the highest for IM(PI1) and corresponds to the homogeneous distribution of $n c-\mathrm{ZnO}$. The values of $I_{10} / I_{20}$ ratio are in a good compliance with $\eta_{B H J} / \eta_{B L H J}$ for the same IMs. For IMs PI1 and PI2 the $I_{10} / I_{20}$ ratio is much higher, than for native surfactant and NPA. This means that the electron transfer from MEH$\mathrm{PPV}$ to $\mathrm{ZnO}$-NC gives the primary contribution in the PL decay process comparing to contribution of the direct exciton recombination in the polymer bulk. Thus, in the both types of MEH-PPV blend films doped with $n c-\mathrm{ZnO}(\mathrm{PI} 1)$ and $n c-\mathrm{ZnO}(\mathrm{PI} 2)$ a signifi- 
Table 3. Device performances of ITO/PEDOT:PSS/MEH-PPV:nc-ZnO(IMs)/Al hybrid photovoltaic devices with different interface modifiers

\begin{tabular}{||c|c|c|c||}
\hline Active layer & $J_{S C} C$ & & \\
\hline MEH-PPV/NC(Nat) & 8.1 & 192 & 20 \\
MEH-PPV/NC(NPA) & 23.7 & 461 & 23 \\
MEH-PPV/NC(PI1) & 13.7 & 244 & 20 \\
MEH-PPV/NC(PI2) & 26.4 & 605 & 24 \\
\hline
\end{tabular}

cant part of the photogenerated excitons can reach the nanocrystals interface within their natural lifetime owing to nanoparticle dispersion state in the polymer host. Decrease of $\eta_{B H J} / \eta_{B L H J}$ ratio means that phase separation arises in the blend system. The trend in direct correlation between the $\eta_{B H J} / \eta_{B L H J}$ data and the film morphology are also retained for the MEH-PPV films containing $n c-\mathrm{ZnO}(\mathrm{Nat})$ and $n c-\mathrm{ZnO}(\mathrm{NPA})$. From Fig. $2 \mathrm{a}$ and $2 \mathrm{~b}$ it follows that the $n c$ $\mathrm{ZnO}$ aggregates are formed in the both $\mathrm{MEH}-\mathrm{PPV} / n c-\mathrm{ZnO}$ (Nat) and $\mathrm{MEH}-\mathrm{PPV} / n c$ $\mathrm{ZnO}$ (NPA) films; the $\eta_{B H J} / \eta_{B L H J}$ values decrease when molecules (PI1) or (PI2) are used as the IMs.

We have also evaluated the overall photovoltaic ITO/PEDOT:PSS/MEH-PPV: $n c$ $\mathrm{ZnO}(\mathrm{IM}) / \mathrm{Al}$ devices performance from the measured current-voltage $(J-V)$ characteristics (Fig. 3) and results for the best set of devices are summarized in Table 3 .

These results indicate that the photovoltaic performance is improved considerably by modifying the interfaces of $\mathrm{MEH}$ $\mathrm{PPV} / n c-\mathrm{ZnO}$ with NPA and PI2 ligands. Among these devices a solar cell that comprises $n c-\mathrm{ZnO}$ modified by PI2 demonstrates the best device performance with $J_{S C}=$ $26.4 \mu \mathrm{A} / \mathrm{cm}^{2}, \quad V_{O C}=605 \mathrm{mV}$, and $F F=$ $24 \%$. Unfortunately, due to relatively narrow spectral absorption range and low holes mobility in the MEH-PPV host as well nonoptimized $n c-\mathrm{ZnO}(\mathrm{IM})$ concentration and thick of the nanocomposite active layer, the power conversion efficiency was rather low value for all devices.

Comparison of the device performance results allows to suggest that the large improvement in $J_{S C}, V_{O C}$ obtained using PI2 can be attributed to lower located LUMO levels than that for Nat or PI1. Lowering of energy barrier for electron injection between MEH-PPV and $n c-\mathrm{ZnO}$, when IMs with lower located LUMO level are used, result in increase of the current density and to decrease of $V_{O C}$ [14]. Instead, the $V_{O C}$ values increase symbatically with $J_{S C}$.

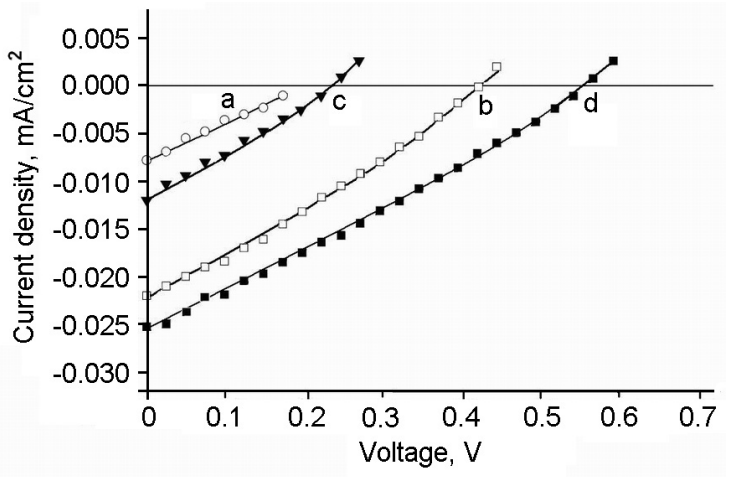

Fig. 3. $J-V$ curves of the ITO/PEDOT:PSS/MEH-PPV: $n c-\mathrm{ZnO}(\mathrm{IM}) / \mathrm{AI}$ cells, containing $\mathrm{ZnO}$ nanocrystals in the active layer with: a - IM(Nat); b - IM(NPA); c - IM(PI1); d - IM(PI2).

Therefore it can be supposed that PI2 molecules serve as the recombination barriers [13] resulting in the raise of electron and hole concentrations at $\mathrm{MEH}-\mathrm{PPV} / n c-\mathrm{ZnO}$ interfaces. This leads to increase of the difference between the quasi-Fermi levels of electrons and holes, and hence to increase in $V_{O C}$. At the same time IM can influence on back recombination kinetics: the IM molecules are more bulky and less planar, the more effective barrier to the back recombination take place $[35,36]$.

\section{Conclusions}

In this work $\mathrm{MEH}-\mathrm{PPV} / n c-\mathrm{ZnO}(\mathrm{IMs})$ nanocomposite films have been fabricated as an active layer for solar cells. The obtained results show that the $n c-\mathrm{ZnO}$ interfacial modification is crucial for the blend film morphology and device performance. Specifically, the IM molecular structure strongly affected the fluorescence lifetime quenching $\left(\tau_{1}\right)$ and the quenching efficiencies $\left(\eta_{q}\right)$ of the BLHJ photovoltaic cells by their energy levels and charge transfer ability. It is found that the IMs can control the phase separation degree of donor and acceptor phases. It is shown that the bulkier molecules of PI1 and PI2, in comparison with the native surfactant and NPA, pro- 
vide effective interaction with the polymer host and thus prevent the nanocrystals aggregation and macroscopic phase separation in the course of the film preparation. All studied herein IMs increase considerably the $P C E$, suggesting the IMs improve essentially the MEH-PPV $/ n c-\mathrm{ZnO}$ interface, promoting dissociation of excitons in the polymer matrix.

Acknowledgments. Financial supports from the National Academy of Science of Ukraine (projects No.0110U003977, No.0112U004502) are gratefully acknowledged. The authors thank to Prof.A.V.Tolmachev for the valued and fruitful discussions.

\section{References}

1. Y.Y.Lin, T.H.Chu, C.W.Chen, W.F.Su, J. Appl.Phys. Lett., 92, 0533121 (2008).

2. M.H.Yum, G.H.Kim, C.Yang, J.Y.Kim, J. Mater. Chem., 20, 7710 (2010).

3. M.A.Ruderer, S.Guo, R.Meier et al., Adv. Funct.Mater., 21, 3382 (2011).

4. L.J.A.Koster, O.Stenzel, S.D.Oosterhout et al., Adv. Ener. Mater., 3, 615 (2013).

5. J.Liu, W.Wang, H.Yu et al., Sol.Energy Mater. Sol.Cells., 92, 1403 (2008).

6. P.Ravirajan, A.M.Peir, M.K.Nazeeruddin et al., J.Phys. Chem., B 110, 7635 (2006).

7. C.Goh, S.R.Scully, M.D.McGehee, J.Appl. Phys., 101, 1145031 (2007).

8. N.Balis, V.Dracopoulos, E.Stathatos et al., $J$. Phys. Chem. C, 115, 10911 (2011).

9. J.-Y.Chen, F.-C.Hsu, Y.-M.Sungc, Y.-F.Chenc, J. Mater. Chem., 22, 15726 (2012).

10. Y.-Y.Lin, Y.-Y.Lee, L.Chang et al., Appl.Phys. Lett., 94, 063308 (2009).

11. R.Thitima, C.Patcharee, S.Takashi, Y.Susumu, Solid-State Electron., 53, 176 (2009).

12. Y.-Y.Lin, T.-H.Chu, S.-S.Li et al., J.Am. Chem.Soc., 131, 3644 (2009).

13. Ch.-W.Hsu, L.Wang, W.-F.Su, J.Coll.Inter. Sci., 329, 182 (2009).
14. S.Erten-Ela, G.Turkmen, Renewable Energy, 36, 1821 (2011).

15. E.Kozma, M.Catellani, Dyes and Pigments, 98, 160 (2013).

16. H.Dincalp, Z.As, C.Zafer, S.Icli, Dyes and Pigments, 91, 182 (2011).

17. M.Wang, X.Wang, Sol.Energy Mater.Sol. Cells, 92, 766 (2008).

18. S.Vajiravelu, R.Lygaitis, J.V.Grazulevicius et al., J.Mater.Chem., 19, 4268 (2009).

19. B.A.Jones, A.Facchetti, M.R.Wasielewski, T.J.Marks， J.Amer.Chem.Soc., 129， 15259 (2007).

20. J.Pan, W.Zhu, S.Li et al., Eur.J.Org.Chem., 4, 986 (2006).

21. C-C.Chao, M-K.Leung, Y.O.Su et al., J.Org. Chem., 70, 4323 (2005).

22. H.Dincalp, S.Icli, Solar Energy, 80, 332 (2006).

23. S.Becker, A.Bohm, K.Mullen, Chemistry, 6, 3984 (2000).

24. J.Li, X.-L.Yu, J.Fu et al., J.Chem.Sci., 122, 839 (2010).

25. W.J.E.Beek, M.M.Wienk, R.A.J.Janssen, Adv. Mater., 16, 1009 (2004).

26. H.Troster, Dyes and Pigments, 4, 171 (1983).

27. M.F.Prodanov, N.V.Pogorelova, A.P.Kryshtal et al., Langmuir, 29, 9301 (2013).

28. Ch.Huang, S.Barlow, S.R.Marder, J.Org. Chem., 76, 2386 (2011).

29. J.Liu, W.Wang, H.Yu et al., Sol.Energ. Mater. Sol.Cells., 92, 1403 (2008).

30. H.Langhals, O.Krotz, K.Polborn, P.Mayer, Angew., Chem.Int. Ed., 44, 2427 (2005).

31. J.Pommerehene, H.Vestweber, W.Guss et al., Adv. Mater., 7, 551 (1995).

32. A.J.Lewis, A.Ruseckas, O.P.M.Gaudin et al., Org. Electron., 7, 452 (2006).

33. K.M.Coakley, Y.Liu, M.D.McGehee et al., Adv. Funct. Mater., 13, 301 (2003).

34. J.-Yu.Chen, F.-Ch.Hsu, Yu-M.Sung, Y.F.Chen, J.Mater. Chem., 22, 15726 (2012)

35. C.Zafer, M.Kus, G.Turkmen et al., Sol. Energ. Mater. Sol. Cell., 91, 427 (2007).

36. A.Burke, S.Ito, H.Snaith, Nano Lett., 8, 977 (2008). 